Open Access

\title{
Sex differences in entrepreneurs' business growth intentions: an identity approach
}

\author{
Leonidas A. Zampetakis ${ }^{1 *}$, Maria Bakatsaki ${ }^{1}$, Konstantinos Kafetsios ${ }^{2}$ and Vassilis S. Moustakis ${ }^{1}$
}

\author{
* Correspondence: \\ Izabetak@dpem.tuc.gr \\ ${ }^{1}$ Technical University of Crete, \\ School of Production Engineering \\ and Management, University \\ Campus, Chania, Crete 73100, \\ Greece \\ Full list of author information is \\ available at the end of the article
}

\begin{abstract}
The present empirical study explores the effects of gender role and cultural identity (masculinity and femininity) in mens' and womens' business growth intentions in established firms. A questionnaire survey was completed by 572 business owners (286 females). Results from moderated mediation regression analyses found that masculinity and femininity fully mediated the effects of entrepreneurs' sex on business growth intentions. Females who had higher femininity orientation and independent self-construal reported lower growth intention compared to those with lower independent self-construal. The study extends theoretical and empirical research on the effects of identity on business growth intentions while applications of the results are discussed.
\end{abstract}

Keywords: Entrepreneurs, Growth intentions, Identity, Gender, Self-construal

\section{Background}

The development and growth of existing business is a process with many societal benefits including job and wealth creation and the advancement of innovation (Tang \& Koveos, 2004; Van Praag \& Versloot, 2007). Entrepreneurs' decision for growing their business is complex, is neither linear nor dependent on a limited number of factors (Miller et al. 2013). Entrepreneurs not only have to make important decisions for different tasks which are different in nature but also have to ensure that those decisions are the right ones not only for their business but also for themselves. While some entrepreneurs are pleased to be self-employed in a small scale, others have growth aspirations for their ventures (Shane, 2009).

Research clearly delineates that women-owned businesses tend to have lower levels of growth and remain smaller than men-owned businesses (Cliff, 1998; Coleman, 2016; Davis \& Shaver, 2012), suggesting the existence of a gap between men and women in entrepreneurship; this is an issue that is attracting increasing academic attention (Coleman, 2016). However, much of that research has investigated differences in the levels of start-up activity between men and women (see Jennings \& Brush, 2013). Little research has examined the growth aspirations of ventures led by women. Compared to male entrepreneurs, female entrepreneurs tend to pursue noneconomic goals such as balancing work and family roles and have preferences for employee relationship and society satisfiers which in turn may detract from economic performance or growth (Eddleston \& Powell, 2008; Jennings \& Brush, 2013).

(c) 2016 The Author(s). Open Access This article is distributed under the terms of the Creative Commons Attribution 4.0 International License (http://creativecommons.org/licenses/by/4.0/), which permits unrestricted use, distribution, and reproduction in any medium, provided you give appropriate credit to the original author(s) and the source, provide a link to the Creative Commons license, and indicate if changes were made. 
As noted by Henry et al. (2016), normative representations of entrepreneurship are dominated by masculinity. This marginalizes female entrepreneurs and renders them invisible. The authors note that whilst the awareness that gender (masculine and feminine) is socially constructed and corresponds to a learned set of behaviors that does not refer to simply the biological sex (male/man and female/woman) of the entrepreneur seems widespread among scholars, several detrimental themes related to women are persistent. For instance, many scholars use male norms to judge women's activities merely comparing men and women, with little or no attention paid to constructions of gender (Ahl, 2006; Lewis, 2006). However, this practice neglects the fact that masculine and feminine aspects will be incorporated into the process of business growth for both men and women. That is to say, gender could be a vital aspect of business growth intention.

Taken together, to date, research does not provide conclusive explanations for the variation in the growth trajectory that men and women would like their venture to follow (i.e., their growth intention) (Bulanova et al. 2016; Dutta \& Thornhill, 2008). Growth intention is considered an essential characteristic of entrepreneurial behavior and a key element in understanding venture development and growth (Sadler-Smith et al. 2003). Moreover, intentions have proven to be the best predictor of planned behavior (Ajzen, 1991), especially if the phenomenon involves unpredictable time lags, planning, and a high degree of cognitive processing, such as business growth (Krueger et al. 2000). Growth intentions are considered a key predictor of actual business growth (Delmar \& Wiklund, 2008; Wiklund \& Shepherd, 2003).

Considerable evidence suggests that an individual's identity (or concept of self) in general (Fauchart \& Gruber, 2011; Hoang \& Gimeno, 2010) and gender identity (or related gender roles) in particular (Eddleston \& Powell, 2008; Gupta et al., 2009) can contribute to substantial differences between men and women in entrepreneurial behavior. People tend to differ in the extent to which they incorporate gender roles into their self-concepts.

In the present study, we propose that entrepreneurs' gender identity or the extent to which entrepreneurs possess traits associated with traditional gender stereotypes (Bem's Sex Role Inventory, 1981; Mueller, 2004; Wood \& Eagly, 2010) is an important cognitive mechanism that relates entrepreneurs' sex to business growth intentions. We argue that gender identity shapes the way entrepreneurs view themselves, how they understand the world around them and approach other people, but also what they aim to achieve in the future (Eddleston \& Powell, 2008; Hoang \& Gimeno, 2010).

However, the mechanisms by which sex and gender identity exert influence on entrepreneurs' growth intentions and the moderating influences that constitute boundary conditions of the theory are in need of further investigation. Self-construal is such a potential moderator of the relationship between gender, gender identity, and growth intentions. Self-construal refers to individuals' culturally contingent thoughts, feelings, and actions that are concerned with one's understanding of the self as connected to others (interdependent self-construal) or distinct from others (independent selfconstrual) (Markus \& Kitayama, 1991). Individuals' exposure to certain conditions can increase the likelihood they exhibit independent (individualistic) or interdependent (collectivistic) tendencies (Hong et al., 2000). The concepts of "entrepreneur" and "entrepreneurship" are considered male-gendered (Ahl, 2006; Lewis, 2006). Cues or symbols in the environment that entrepreneurs utilize to operate their business could make independent self-construal more accessible (Hong et al., 2000), since the 
masculine identity highlights individuals' unique attributes (Cross \& Madson, 1997). A systematic consideration of the potential moderating effects of self-construal will contribute to a fuller understanding of the conditions under which the effects of sex on growth intentions are more likely to hold.

In sum, the aim of this article is to deepen the understanding of the factors that influence business growth motivation in established firms. Towards this end, one major aim of the present study is to examine the relationship between entrepreneurs' sex, gender identity, and business owner's growth intentions of their established ventures. We reasoned that an exploration into the growth intentions of business owners of established firms might help explain sex differences in the decision to grow. A second major purpose of the present study is to focus on entrepreneurs' selfconstrual as a potential moderator of the relationship between sex and gender identity and between gender identity and business growth intention (see conceptual model in Fig. 1). To the best of our knowledge, to date, there has been little research explaining the influence of these domains and entrepreneurs' intention for the growth established business. However, this is important considering that individuals start and operate their ventures for a variety of reasons other than growth or maximizing economic returns (Wiklund et al. 2003).

The paper commences with an analysis of business growth intentions; this is followed by an evaluation of the influence of gender identity on growth intentions and the moderating role of self-construal. Next, we describe our sample, research methods, and data analysis techniques which include ANOVA and moderated mediation analyses. Finally, we discuss the outcomes of the empirical analysis and the limitations of the research, present the practical implication of research results, and propose areas for further research.

\section{Growth intention and entrepreneurs' gender identity}

Business growth is a multidimensional and complex phenomenon that involves careful planning and thinking on the part of the entrepreneur. As such, business growth can be considered a deliberate and planned intentional behavior and consequently applicable for intention models (Ajzen, 1991; Krueger et al., 2000). Growth

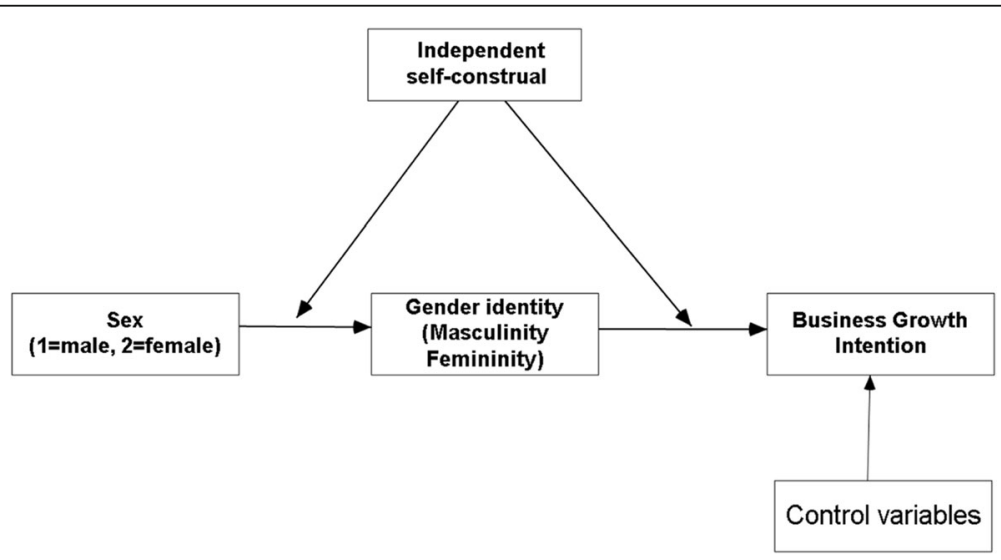

Fig. 1 Representation of the hypothesized theoretical model 
intentions are central to the understanding of business growth as they are the first step in the process and involve a purposive element with specific steps to reach the goal (Delmar \& Wiklund, 2008; Venugopal, 2016). Intentions have been identified as a key predictor of actual behavior, across a wide range of different behaviors including business startup (Delmar \& Wiklund, 2008; Wiklund \& Shepherd, 2003). Moreover, research provides evidence that the proportion of entrepreneurs with growth intentions in the population is a significant predictor of economic growth compared to self-employment rates or general start-up rates (Stam et al., 2009).

Up to date, research on entrepreneurs' growth intentions has produced mixed results regarding empirical differences between men and women and not all scholars agree that women and men differ in their overall business growth intent (Cassar, 2006; Davis \& Shaver, 2012). For instance, Cassar (2006) found that women entrepreneurs had lower estimates of future revenues than did men. However, Menzies et al. (2004), in a study conducted in Canada, found no statistically significant differences between women and men in their expressed preferences for unrestrained growth. In the present study, we propose that gender socialization processes may explain differences between male and female entrepreneurs' business growth intentions.

Contemporary research in entrepreneurship suggests that decisions such as the growth of established ventures are intimately intertwined with the entrepreneurs' identity (Shepherd \& Haynie 2009). Identity is a fluid social process that has a range of conceptual meanings and theoretical roles associated with it (Fauchart \& Gruber, 2011; Hoang \& Gimeno, 2010). It can be viewed as peoples' representation of the internalization and incorporation of socially held behavioral expectations. Moreover, identity can be regarded as a fundamental bridging concept between the individual and the social (Hoang \& Gimeno, 2010). Individuals are socially constructed through social interactions and that they acquire throughout their lives diverse and multiple social identities. In the case of the entrepreneurial process, Ireland and Webb (2007) note in their review that for entrepreneurs, the entrepreneurial process is based on and driven by selfidentities. Recent conceptual models of the role of identity in entrepreneurship propose strong links between entrepreneurs' self-concept and entrepreneurial actions and outcomes (Shepherd \& Haynie 2009), but to date, empirical research is limited (Farmer et al. 2011). Gender identity is considered an essential element of a many-sided conception of the self that situates individuals within social structures (Eddleston \& Powell, 2008; Wood \& Eagly, 2010). Gender is different from sex (Ahl, 2006). Researchers have distinguished sex from gender during the 1970s and 1980s to distinguish between biological characteristic of males and females and the meanings that societies and individuals ascribe to male and female categories (Bem's Sex Role Inventory, 1981; Wood \& Eagly, 2010). Individuals throughout the life course are taught (implicitly or explicitly) which behaviors and roles are desirable for men or women in society. As such, most individuals accept or internalize the cultural meanings associated with their sex meanings. Gender identity represents the extent to which an individual believes that he or she possesses traits associated with traditional gender stereotypes (Bem's Sex Role Inventory, 1981; Wood \& Eagly, 2010).

People differ in the extent to which they incorporate gender roles into their selfconcepts. Two independent dimensions of gender identity arise: masculinity, or beliefs about the extent to which one possesses traits associated with males (e.g., dominance, independence, ambition) and femininity, or beliefs about the extent to which one possesses 
traits associated with females (e.g., sensitivity to the needs of others, compassion, understanding) (Eddleston \& Powell, 2008; Wood \& Eagly, 2010). Women are socialized to identify with attributes that are considered feminine, and men are socialized to identify with attributes that are considered masculine (Bem's Sex Role Inventory, 1981). As such, male entrepreneurs are more likely to exhibit a stereotypical masculine orientation and female entrepreneurs are most likely to exhibit a stereotypical feminine orientation (Bird \& Brush, 2002).

People use their gender identity as a standard against which to regulate their behavior. Entrepreneurs who have a masculine self-concept involving independence and dominance might regulate their behavior by, for example, seeking opportunities for high growth and financial rewards from their businesses (Bird \& Brush, 2002). Eddleston and Powell (2008) in their survey of entrepreneurial alumni show that women entrepreneurs value different sources of career satisfaction than men. Male entrepreneurs preferred satisfiers associated with status attainment (e.g., earning a lot of money, having high prestige and social status, being in a leadership role, leading a large, rapidly growing enterprise) whereas female entrepreneurs preferred satisfiers associated with employee relationships (e.g., working with friendly and congenial people, having supportive employees, working as part of a team) and making a contribution to society. Nevertheless, the study presents no evidence on whether business owners' masculinity relates more strongly to growth intentions compared to business owners' femininity.

\section{Boundary conditions: the role of independent self-construal}

Research provides convincing evidence that the concept of entrepreneurial activity is genderbiased: Entrepreneurship is often depicted as a form of masculinity and the terms "entrepreneur" and "male" have tended to become interchangeable (Ahl \& Marlow 2012; Gupta et al., 2009). This supports an hierarchical valuation in which the masculine is prioritized over the feminine and the characteristics of successful business owners (i.e., proactivity, need for achievement, risk taking competiveness, confidence) are stereotypically perceived to be masculine (Ahl, 2006; Bird \& Brush, 2002; Coleman, 2016). Moreover, the behavior of women involved in entrepreneurial activity is defined and evaluated according to the standards of an invisible masculine norm (Lewis, 2006). Women entrepreneurs have to manage different identities simultaneously which can result in conflict (Ahl, 2006; Bird \& Brush, 2002).

Accordingly, to be recognized as credible actors within entrepreneurship, women have to learn the delicate balance between adopting a credible entrepreneurial identity which reflects masculinized norms but without denying ascribed femininity (Ahl \& Marlow 2012). Thus, one important question raised is how women entrepreneurs' growth intentions are formed despite the mixed messages they receive from a process that broadly emphasizes masculinity but also expects females specifically to care for and nurturing children or maintaining the household, or be supportive, that is, interdependent and connected with others. Building on the cultural dimensions of individualism and collectivism Cross and Madson (1997) propose additional facets of gender identity reflecting investment in an individual versus social sense of self. The authors define masculine identity as an independent sense of self and feminine identity as an interdependent sense of self.

Specifically, independent and interdependent self-construals represent one of the most fundamental and overarching schemata of an individual's selfhood (Markus \& Kitayama, 1991; Oyserman et al., 2002). Self-construal refers to the way an individual understands oneself in relation to other people. A person possessing an independent 
self-construal views one's self as separate from others, aiming to maintain a sense of autonomy and uniqueness. A person possessing an interdependent self-construal views one's self as connected to others, where self-presentations are woven together with representations of close others and social context (Markus \& Kitayama, 1991; Oyserman et al., 2002). Men are more likely to be likely to be socialized to construct an independent self-construal and develop a social self that is marked by placing primary emphasis on values of individual needs, autonomy, and self-fulfillment. Women are more likely to be socialized to construct an interdependent self-construal and develop a social self that is marked by the motivation to be connected with particular relationships or contexts (Cross \& Madson, 1997; Oyserman et al., 2002; Singelis, 1994).

There is limited research to date that has assessed the relationship between selfconstrual and entrepreneurship. Recent empirical research provides evidence for the moderating role of individual-level self-construal in cognitive models of intention to start a new business (Siu \& Lo, 2013; Zampetakis et al., 2015). For instance, Siu and Lo (2013), using a sample of students from China and Hong Kong, found that the strength of perceived social norms in predicting entrepreneurial intention was dependent on interdependent self-construal. Zampetakis et al. (2015) using a sample of students from Greece found that independent self-construal was related to attitudes towards entrepreneurship and moderated relationships between attitudes and entrepreneurial intentions.

As noted above, in order for women to gain legitimacy as entrepreneurs, they are encouraged to adopt and reproduce attitudes and behaviors which are in fact reproductions of what men do and what men are (Ahl \& Marlow, 2012). However, some evidence suggests that when women emulate the behavior of the idealized male, there is evidence of misfit. For instance, Kerfoot and Miller (2010) evaluated the results of a training program for potential business owners aiming to encourage more women to start their own ventures. The program established men as natural entrepreneurs rendering women as outsiders, and the only hope for entry in the entrepreneurial process was by learning how to emulate the behavior of the idealized male. After undertaking the course, many of the potential female business owners were actively discouraged from starting new ventures. It became evident that they did not "fit" the masculinized image of an entrepreneur (Kerfoot \& Miller, 2010).

This suggests that when cues or symbols in the environment make independent selfconstrual more accessible (Hong et al., 2000; Oyserman \& Sorensen, 2009) (i.e., symbols of individual freedom, autonomy, personal fulfillment, and separation), then feminine entrepreneurs may have less need for growing their ventures because of the conflict inherent in the relation between independent self-construal and femininity. Specifically, individuals who see themselves as higher in femininity are more likely to consider themselves as a member of a group. This in turn prompts a cognitive style that is concerned with the negative consequences of behavior (that is business growth) and avoiding potential failure (Oyserman \& Sorensen, 2009). Thus, we expect that the interaction between independent self-construal and femininity for the prediction of growth to be negative.

\section{Overview of study aims and hypotheses}

The purpose of the present study was to examine differences in the process of business growth of established firms, between male and female entrepreneurs. We focused on a 
specific aspect of firm growth-the intention of the entrepreneur-and whether and how biological sex, gender identity, and independent self-construal affect growth intentions.

Specifically, the study aimed firstly to determine whether and the extent to which biological sex is associated with gender identity and entrepreneurs' business growth intentions. We expected that the correlation between entrepreneurs' sex and gender identity to be strong such that male entrepreneurs are most likely to exhibit a stereotypical masculine orientation and female entrepreneurs are most likely to exhibit a stereotypical feminine orientation. Secondly, we aimed to test whether, and the extent to which, gender identity mediates biological sex effects on business growth intentions. We expected that gender identity would at least partially mediate biological sex effects on growth intentions; we expected the effect of masculinity on growth intentions to be stronger compared to the effect of femininity. Finally, we examined the moderating influences of independent self-construal that constitute boundary conditions of the theory. We expected that independent self-construal would moderate the relationship between sex and gender identity and between gender identity and growth intentions. To our knowledge the present study is one of the first to examine within-culture individual-level cultural orientations as antecedents to business growth intentions in some depth.

We conducted a moderated mediation analysis (Hayes, 2013) in order to clearly distinguish the mediatory power of gender identity and the moderating role of independent self-construal while controlling for both firm-level and individual-level variables.

\section{Methods}

\section{Participants and procedures}

Entrepreneurs were selected from email lists of businesses drawn from inventories held by champers, and municipalities of regional governments in a country in south Europe were invited to participate in the study through personal contact by the authors. Entrepreneurs were given the following explanation for the purposes of the study: "This is an effort to combine research into how entrepreneurs run their businesses and get insights of the values and desires that make people like you successful. You will answer a questionnaire without filling in anything that will identify you, or your business and the results will be used to better understand how entrepreneurship progress in your area."

Five entrepreneurs provided comments on the survey instrument. After reviewing comments from these individuals, we made minor modifications to the instrument. Entrepreneurs who agreed to participate in the survey were sent the research instrument to complete by email or fax. A total of 2600 questionnaires were distributed, and 613 entrepreneurs completed useable surveys. To maximize the reliability and generalizability of our results, we employed an instructional manipulation check (Oppenheimer et al. 2009). More specifically, one of the survey questions was presented in a very similar way as other questions, except it was followed by a parenthesis in which the respondents were informed that the question was intended to check whether they were paying proper attention and that they should select the first choice for this particular question. The respondents who failed to make the instructed choice were dropped from the analysis. This process resulted in 572 entrepreneurs representing a response rate of $22 \%$. Data collection took place during January and April 2016. 
The sample included 286 males (50\%) aged between 21 and 61 years $(M=44.83$ years, $\mathrm{SD}=8.37$ years). Average number of years of business operation was 13.67 years $(\mathrm{SD}=9.09), 44.8 \%$ of the respondents had a college/university degree $(12.8 \%$ had $\mathrm{Msc} / \mathrm{PhD}$ degrees), and $32.2 \%$ had a parent that owned a business. On average, entrepreneurs reported having nine employees $(\mathrm{SD}=47.73)$ for each firm. Within our sample, entrepreneurs' activities represent different domains. The most frequently indicated domains were tourism (391\%), food production (21\%), property and business services (13), finance and insurance (12\%), health and community services (9\%), construction (4\%), and smaller percentage in other activities.

\section{Measurement of theoretical constructs}

All the main constructs included in the analysis were assessed with self-report measures based on multi-item scales. Native speakers translated all the items into the Greek language. A back-translation into English by other bilingual individuals revealed that the translation had worked quite well and that the wording had similar connotations. The specific measures used in the analysis, along with sample items of the relevant constructs, are outlined.

\section{Gender identity}

To measure masculinity and femininity, a short form of the Bem's Sex Role Inventory (BSRI; Bem's Sex Role Inventory, 1981) was used. The short BSRI contains six items for each masculine and feminine dimension. These items have been validated in previous research (Carver et al., 2013; Vafaei et al., 2014). Entrepreneurs rated the extent to which six masculine items (with leadership abilities, possessing strong personality, dominant, act like a leader, make decision easily, and defend own beliefs) and six feminine items (warm, gentle, affectionate, sympathetic, sensitive to others' needs, and tender) described themselves on a 7 -point scale ( 1 = not at all like me, 7 = very much like me). The masculine items were averaged to yield a masculine score (Cronbach's reliability coefficient $=0.83$ ), and the feminine items were averaged to yield a feminine score (Cronbach's reliability coefficient $=0.79$ ).

\section{Business growth intentions}

To assess business growth intentions, we used two items from previous research (Davis \& Shaver, 2012; Edelman et al., 2010). Entrepreneurs rated the extent to which they agreed with the two items using a 7-point Likert-type scale ranging from (1) strongly disagree to (7) strongly agree. The two items were (1) "I want my business to be as large as possible" and (2) "I want a size I can manage myself or with a few key employees" (reverse scored). The items were averaged to yield a growth intentions score (Cronbach's reliability coefficient $=0.83$ ).

\section{Biological sex}

Sex was measured as a dummy variable with men coded as 1 and women coded as 2 .

\section{Self-construal}

We assessed independent and interdependent self-construal using a shortened version of the original Singelis (1994) self-construal scale, a measure of chronic or trait self-construal (Fernández et al. 2005). Respondents indicated their level of agreement with each items using a 7-point Likert-type scale ranging from (1) strongly disagree 
to (7) strongly agree. The independent self-construal subscale (IND) contained six items that assess uniqueness, personal reward and "less contextualized self" in social behavior ((1) "I enjoy being unique and different from others in many respects," (2) "I am comfortable with being singled out for praise or rewards," (3) "My personal identity is independent of others is very important for me," (4) "I act the same way no matter who I am with," (5) "I prefer to be direct and forthright when dealing with people I've just met," (6) "I'd rather say "no" directly, than risk being misunderstood"). Cronbach's alpha coefficient for this scale was 0.65 . The interdependent selfconstrual subscale (INTER) included seven items that assessed connectedness in social behavior concerning in-groups ((1) "I would stay in a group if they needed me even if I were not happy with the group," (2) "I will sacrifice my self-interest for the benefit of the group I am in," (3) "I often have the feeling that my relationships with others are more important than my own accomplishments," (4) "It is important for me to respect decisions made by the group," (5) "My happiness depends on the happiness of those around me," (6) "I respect people who are modest about themselves," "It is important for me to maintain harmony within my group," (7) "It is important to me to respect decisions made by the group"). Cronbach's alpha coefficient for this scale was 0.76 .

\section{Control variables}

As controls, we used both firm-level and individual-level variables. The firm-level controls included self-reported questions about firm age, number of employees, and the performance of the firm. Firm age was measured as the number of years since the firm had been established. Firm performance was measured by entrepreneurs' subjective reports of their firms' performance relative to that of other ventures in their industry (Perf1-"Relative to competing products/services, those of my business have been more successful in terms of sales"; Perf2-"Relative to competing products/services, those of mu venture have been more successful in terms of achieving and establishing market share" (Cronbach's alpha $=0.81$ ).

The individual-level controls included the age of the entrepreneur, the education level, internal locus of control, and perceived behavioral control. Younger entrepreneurs are likely to be more eager to grow than older entrepreneurs. Education level was measured with a four-point ordinal scale with higher values indicating a higher level of education. Previous research suggests a positive relationship between entrepreneur's internal locus of control and success of small-scale enterprises (Rauch \& Frese, 2000). Entrepreneurs with an internal locus of control (InLOC) believe that they have control of their destiny. It was assessed using the five-item scale (Cronbach's reliability coefficient $=0.74$ ) presented in Chen et al. (1998). Finally, we controlled for entrepreneurs' perceived behavioral control $(\mathrm{PBC})$ that is entrepreneurs' beliefs that they are capable of performing a given behavior. Venugopal (2016) using the theory of planned behavior (Ajzen, 1991) found that self-efficacy (a construct with conceptual similarities with $\mathrm{PBC}$ ) had a direct positive effect on business growth intentions. However, the effects of both attitudes towards growth and subjective norms on growth intentions were not significant. We assessed entrepreneurs' PBC by adopting two items from the scale of Linan and Chen (2009). Items are as follows: (1) "I can control the growth 
process of my firm," (2) "It is easy to manage the sales growth of my business" (Cronbach's reliability coefficient $=0.81$ ).

\section{Measurement model}

To examine the within and between statistical structure of the measurement scales used, we conducted a four-factor confirmatory analysis in Analysis of Moment Structures (AMOS version 7.0) software (Arbuckle, 2006) using the indicators for gender identity (masculinity, femininity), independent self-construal, and growth intentions. Goodness of fit was determined using the root mean square error of approximation (RMSEA) and the comparative fit index (CFI), and commonly used threshold values were used as indicators of poor fit (RMSEA $\geq 0.08$ and CFI $\leq 0.90$ ) (Shook, et al., 2004). The Akaike Information Criterion (AIC) was used for model comparisons; smaller values indicate better fitting model. Overall, the hypothesized measurement model fit the data quite well when evaluated in terms of the recommended cutoffs or the combination cutoff approach: $\chi^{2}(155, N=572)=418.11, p=0.00$; RMSEA $=0.055$ (90\% CI 0.048 to 0.060 ); $\mathrm{CFI}=0.928$; and $\mathrm{AIC}=568.10$. The four-factor model was then compared to a measurement model that specified perfect correlation among all four latent variables, in order to test overall discriminability.

The one-factor model also provides a test for common method bias (Podsakoff, et al., 2003). The hypothesized measurement model fit the data better than a single factor model: $X^{2}(158, N=572)=594.29, p=0.00$; RMSEA $=0.088$ (90\% CI 0.079 to 0.096 ); $\mathrm{CFI}=0.881$; and $\mathrm{AIC}=738.29$ ) both in terms of the fit statistics and when directly contrasted with a change in AIC. In summary, the results suggest that the proposed factor structure presents a statistically adequate and sufficient fit to the data, indicating the absence of severe common method variance.

\section{Statistical analysis approach}

The main statistical procedure used was conditional process analysis (Hayes, 2013). The analysis was conducted using model 58 in the PROCESS macro developed by Hayes (Hayes, 2013). We used a bootstrap procedure (and the bias corrected method) that generated a sample size of 5000 for our regression analyses (Shrout \& Bolger 2002). The independent variable was $\operatorname{sex}(1=$ male, $2=$ female $)$, and the dependent variable was business growth intention. The mediating variables were masculinity and femininity. These were entered as mediators operating in parallel.

Independent self-construal was entered as a continuous moderator variable that influenced the paths from sex to each of the mediating gender identity variables (first stage of the mediated effect of sex on growth intentions) and moderated the paths from each of the gender identity variables to business growth intention (the second stage of the mediated effect of sex on growth intentions) (see Fig. 1). All independent variables were standardized before being entered into the regression. In addition, all interactions were graphed using procedures described by Cohen, et al. (2003). Each graph was plotted at 1 standard deviation above and below the mean.

\section{Results}

Means, standard deviations, and bivariate correlations for all measured items are shown in Table 1. We conducted multiple analyses in order to examine multicollinearity in 
Table 1 Means, standard deviations, and intercorrelations among variables

\begin{tabular}{|c|c|c|c|c|c|c|c|c|c|c|c|c|c|c|c|}
\hline Variable & M & SD & 1 & 2 & 3 & 4 & 5 & 6 & 7 & 8 & 9 & 10 & 11 & 12 & 13 \\
\hline 1. Sex & 1.50 & 0.50 & 1.00 & & & & & & & & & & & & \\
\hline 2. Age & 44.83 & 8.37 & $-0.13^{* *}$ & 1.00 & & & & & & & & & & & \\
\hline 3. Education level ${ }^{\mathrm{b}}$ & 2.60 & 0.84 & 0.04 & $-0.23^{* *}$ & 1.00 & & & & & & & & & & \\
\hline 4. Internal locus of control & 5.38 & 0.87 & -0.03 & 0.00 & 0.07 & 1.00 & & & & & & & & & \\
\hline 5. Perceived behavioral control & 4.97 & 1.29 & $-0.10^{*}$ & 0.03 & 0.05 & $0.33^{* *}$ & 1.00 & & & & & & & & \\
\hline 6. Years of firm operation & 13.67 & 9.09 & $-0.15^{* *}$ & $0.48^{* *}$ & $-0.18^{* *}$ & 0.01 & 0.01 & 1.00 & & & & & & & \\
\hline 7. Number of employees & 9.15 & 47.73 & $-0.08^{*}$ & 0.02 & $0.14^{* *}$ & 0.07 & 0.02 & 0.01 & 1.00 & & & & & & \\
\hline 8. Firm performance & 5.02 & 1.02 & -0.06 & -0.02 & 0.09 & $0.37^{* *}$ & $0.33^{* *}$ & $0.09^{*}$ & $0.09^{*}$ & 1.00 & & & & & \\
\hline 9. Masculinity & 4.91 & 1.07 & $-0.14^{* *}$ & 0.01 & $0.15^{* *}$ & $0.41^{* *}$ & $0.21^{* *}$ & -0.01 & $0.10^{*}$ & $0.32^{* *}$ & 1.00 & & & & \\
\hline 10. Femininity & 5.52 & 0.90 & $0.18^{* *}$ & -0.06 & -0.02 & $0.24^{* *}$ & 0.07 & -0.04 & -0.04 & $0.13^{* *}$ & $0.21^{* *}$ & 1.00 & & & \\
\hline 11. Independent self-construal & 5.18 & 0.84 & 0.06 & -0.01 & 0.02 & $0.35^{* *}$ & $0.11^{* *}$ & -0.03 & 0.03 & $0.13^{* *}$ & $0.44^{* *}$ & $0.26^{* *}$ & 1.00 & & \\
\hline 12. Interdependent self-construal & 5.36 & 0.88 & 0.04 & 0.04 & -0.05 & $0.10^{* *}$ & $0.15^{* *}$ & 0.02 & 0.00 & $0.10^{* *}$ & 0.03 & $0.38^{* *}$ & $0.34^{* *}$ & 1.00 & \\
\hline 13. Business growth intention & 5.33 & 1.45 & 0.00 & -0.06 & 0.02 & $0.28^{* *}$ & $0.36^{* *}$ & $-0.10^{*}$ & 0.07 & $0.17^{* *}$ & $0.24^{* *}$ & $0.19^{* *}$ & $0.20^{* *}$ & $0.16^{* *}$ & 1.00 \\
\hline
\end{tabular}

$N=572$
a $S e x$ is coded such that $1=$ male and $2=$ female

${ }^{\mathrm{b}}$ Education level: 1 = primary education, $2=$ secondary education, $3=$ university $/$ college, $4=\mathrm{M} . \mathrm{Sc} / \mathrm{Phd}$ ${ }^{*} p<0.05,{ }^{* *} p<0.01$ (two-tailed tests) 
our data. The highest correlation between any pair of independent variables was 0.48 (see Table 1), no variance inflation scores were greater than $1.55(M=1.33)$ (below the value of 10 that is seen as problematic), and all conditional index scores were less than 25.61. These tests show multicollinearity not to be a concern, as each of these results falls well within acceptable ranges (Cohen, et al., 2003).

Analyses using independent $t$ tests indicated significant differences between male and female respondents in terms of age $[t(507)=3.021, p<0.001]$; number of employees $[t(570)=2.031, p<0.001]$; firm age $[t(570)=3.588, p<0.001]$; perceived behavioral control $[t(570)=2.311, p<0.001]$; masculinity $[t(570)=3.336, p<0.001]$; and femininity $[t(570)=-4.261, p<0.001]$. No significant differences were observed in terms of education level, growth intention, internal locus of control, and independent and interdependent self-construal.

Growth intention in established firms was positively related to entrepreneur's internal locus of control $(r=0.28, p<0.01)$, perceived behavioral control of business growth $(r=0.36, p<0.01)$, firm performance $(r=0.17, p<0.01)$, masculinity $(r=0.24, p<0.01)$, femininity $(r=0.19, p<0.01)$, independent self-construal $(r=0.20, p<0.01)$, and interdependent self-construal $(r=0.16, p<0.01)$. Growth intention was not related to entrepreneur's age. Years of firm operation was negatively related to growth intent $(r=-0.10$, $p<0.05)$. However, there was a small but significant correlation between years of firm operation and firm performance suggesting that firm performance increases with firm age (Haltiwanger et al. 1999).

Masculinity was negatively related to sex $(r=-0.14, p<0.01)$ while femininity was positively related to sex $(r=0.18, p<0.01)$. This suggests that male entrepreneurs are higher in masculinity and lower in femininity than female entrepreneurs, in line with previous research on business owners (Eddleston \& Powell, 2008). Cross-tabulation analysis results of entrepreneurs by sex and gender identity suggested that males were most likely to be categorized as masculine (56.3\%) and least likely to be categorized as feminine (43.8 \%). Women were most likely to be categorized as feminine $(71 \%)$ and least likely to be categorized as masculine (29\%). These results are in line with our expectation, that is, male entrepreneurs are most likely to exhibit a stereotypical masculine orientation and female entrepreneurs are most likely to exhibit a stereotypical feminine orientation. Masculinity was more strongly related to business growth intentions $(r=0.24, p<0.01)$ compared to femininity $(r=0.19, p<0.0)$. However, using the Fisher $r$-to- $z$ transformation (Cohen et al., 2003), the significance of the difference between the two correlation coefficients was not statistically significant ( $p=0.53$, two tailed).

The relationship between sex and business growth intention was not statistically significant. However, recent developments in the research method literature suggest that it is not necessary to assume a direct effect between the independent and dependent variables to be mediated (Hayes, 2013; Zhao et al. 2010). According to Zhao et al. (2010), the mediating effect should be tested by estimating and bootstrapping the significance of the indirect effects between the independent, mediator, and dependent variables (Shrout \& Bolger 2002). In order to estimate the indirect effect of sex on business growth intentions through masculinity and femininity, we used model 4 in the PROCESS macro developed by Hayes (Hayes 2013).

The mediation analysis was controlled for firm age, number of employees, firm performance, entrepreneur's age, education, internal locus of control, and perceived 
behavioral control. Accordingly, the suggested mediational model was significant: $F(10,561)=14.13, p=0.000)$. Sex significantly related to the mediators [femininity: $\beta=0.35,95 \% \mathrm{CI}=0.19$ to 0.51 ]; [masculinity: $\beta=-0.28,95 \% \mathrm{CI}=-0.44$ to -0.11 ]. Furthermore, the mediators significantly related to business growth intention [femininity: $\beta=0.11,95 \% \mathrm{CI}=0.03$ to 0.19 ]; [masculinity: $\beta=0.12,95 \% \mathrm{CI}=0.03$ to 0.20 ]. The indirect effect of sex on business growth through both femininity $[B=0.0388,95 \% \mathrm{CI}=0.02$ to 0.09$]$ and masculinity $[\beta=-0.0324,95 \% \mathrm{CI}=-0.07$ to -0.02$]$ was statistically significant. Results suggest that masculinity and femininity completely mediated the effect of sex on business growth intentions. Moreover, results of indirect effect contrast definitions suggest that the indirect effect via femininity is greater than the effect via masculinity [the difference is $0.07,95 \% \mathrm{CI}=0.03$ to 0.12]. All estimated regression parameters are standardized. Still, these effects are relative small (Preacher and Kelley, 2011).

We expected that the indirect effect of biological sex on business growth intention is conditional on independent self-construal (IND). That is, gender identity (femininity and masculinity) mediates the relationship between biological sex and growth intentions, and IND moderates the paths from sex to gender identity (first stage moderation) and from gender identity to growth intentions (second stage moderation). As shown in Table 2, for the first stage moderation, the sex X IND interaction was statistically significant for femininity $[\beta=-0.19,95 \% \mathrm{CI}=-0.35$ to -0.11$]$ but not masculinity. The direct positive effect of sex on femininity was stronger at lower levels of IND. For low levels of IND (1SD below mean), the effect of sex on femininity was $\beta=0.52$, $95 \%$ $\mathrm{CI}=0.30$ to 0.73 . For high levels of IND (1SD above the mean), the effect of sex on femininity was $\beta=0.13,95 \% \mathrm{CI}=-0.09$ to 0.34 that is not statistically significant.

For the second stage moderation, both femininity and masculinity related positively to business growth intentions (see Table 2). However, only the interaction IND X femininity was statistically significant: $\beta=-0.09,95 \% \mathrm{CI}=-0.17$ to -0.05 . The nature of the interaction was tested by calculating simple slopes at \pm 1 standard deviation of IND (Fig. 2). The effect of femininity on growth intention was stronger at lower levels of IND [ -1 SD below mean: $\beta=0.21,95 \% \mathrm{CI}=0.10$ to 0.31 ]. For high levels of IND, the effect of femininity in growth intention is not significant.

Following Hayes (2013), bootstrapping techniques were used to assess the significance of the conditional indirect effect of sex on growth intention. The estimates and bootstrapped $95 \%$ confidence intervals for the conditional indirect effects are presented in Table 3. The pattern of results shown in Table 3 suggests that the indirect effect of biological sex on business growth intentions (via gender identity) is contingent on entrepreneur's independent self-construal, such that the indirect effect (via femininity) increases as the entrepreneur's independent self-construal decreases.

We have repeated the analyses using interdependent self-construal as the moderator variable. Results suggest that interdependent self-construal is not a significant moderator of the indirect effect of biological sex on business growth intentions (via gender identity).

\section{Discussion}

The present study had two primary goals: (a) to examine whether and how gender role identity (i.e., one's masculinity and femininity orientation) can explain effects of 
Table 2 Test of first and second stage moderated mediation model

\begin{tabular}{|c|c|c|c|}
\hline \multirow{3}{*}{ Predictor } & \multicolumn{2}{|l|}{ First stage moderation } & \multirow{2}{*}{$\begin{array}{l}\text { Second stage } \\
\text { moderation } \\
\text { Business growth } \\
\text { intention }\end{array}$} \\
\hline & Femininity & Masculinity & \\
\hline & B & B & $B$ \\
\hline Constant & $0.48^{* *}(-0.72$ to -0.23$)$ & $0.49^{* *}(0.26$ to 0.72$)$ & $0.07^{\text {ns }}(-0.23$ to 0.25$)$ \\
\hline $\operatorname{Sex}^{a}$ & $0.32^{* *}$ (0.16 to 0.48$)$ & $-0.32^{* *}(-0.47$ to -0.18$)$ & $0.02^{\text {ns }}(-0.13$ to 0.17$)$ \\
\hline Age & & & $0.001^{\text {ns }}(-0.09$ to 0.08$)$ \\
\hline Education level $^{\text {b }}$ & & & $-0.06^{\text {ns }}(-0.14$ to 0.02$)$ \\
\hline $\begin{array}{l}\text { Entrepreneur's internal locus } \\
\text { of control }\end{array}$ & & & $0.08^{\text {ns }}(-0.02$ to 0.17$)$ \\
\hline $\begin{array}{l}\text { Entrepreneur's perceived } \\
\text { behavioral control }\end{array}$ & & & $0.31^{* *}(0.23$ to 0.38$)$ \\
\hline Firm age & & & $-0.09^{*}(-0.18$ to -0.03$)$ \\
\hline Number of employees & & & $0.05^{\text {ns }}(-0.02$ to 0.13$)$ \\
\hline Firm performance & & & $-0.02^{\text {ns }}(-0.10$ to 0.06$)$ \\
\hline Femininity & & & $0.10^{* *}(0.09$ to 0.18$)$ \\
\hline Masculinity & & & $0.10^{* *}(0.08$ to 0.19$)$ \\
\hline Independent self-construal (IND) & $0.54^{* *}(0.29$ to 0.80$)$ & $0.44^{* *}(0.20$ to 0.68$)$ & $0.05^{\text {ns }}(-0.03$ to 0.14$)$ \\
\hline Sex X IND & $-0.19^{*}(-0.35$ to -0.11$)$ & $0.03^{\text {ns }}(-0.14$ to 0.14$)$ & \\
\hline IND $X$ femininity & & & $-0.09^{*}(-0.17$ to -0.05$)$ \\
\hline IND X masculinity & & & $-0.03^{\text {ns }}(-0.09$ to 0.03$)$ \\
\hline \multicolumn{4}{|c|}{$\begin{array}{l}\text { The upper and lower bounds of the } 95 \% \text { confidence interval (shown in parentheses) were based on the findings from a } \\
\text { bootstrapping analysis using the percentile method }\end{array}$} \\
\hline
\end{tabular}

entrepreneurs' sex on business growth intentions in established firms and (b) to explore the role of independent self-construal regarding this possible mediation effect. In particular, we were interested in finding out whether independent self-construal moderates the indirect effects of sex on business growth intentions. Results from conditional process analysis (Hayes, 2013) suggested that masculinity and femininity fully mediated the effects of entrepreneurs' biological sex on his/her business growth intentions. Moreover, results provided evidence that the indirect effect of sex on business growth intentions (via femininity) was contingent on entrepreneurs' independent selfconstrual.

The primary contribution of this research is that it is the first to empirically demonstrate that gender identity constitutes an important part in conceptual models that explain sex differences in business growth intentions (Bulanova et al. 2016; Davis \& Shaver, 2012; Venugopal, 2016). The study of business growth intentions is important since the growth intentions of entrepreneurs are found to be positively related to subsequent firm growth (Delmar \& Wiklund, 2008; Wiklund \& Shepherd, 2003). Moreover, our results suggest that women entrepreneurs tend to have lower business growth intentions at high levels of independent self-construal. The salience of independent self-construal, assumed to be more typical of men, results in conflict to women entrepreneurs who have to manage different identities simultaneously (Ahl, 2006; Bird \& Brush, 2002). 


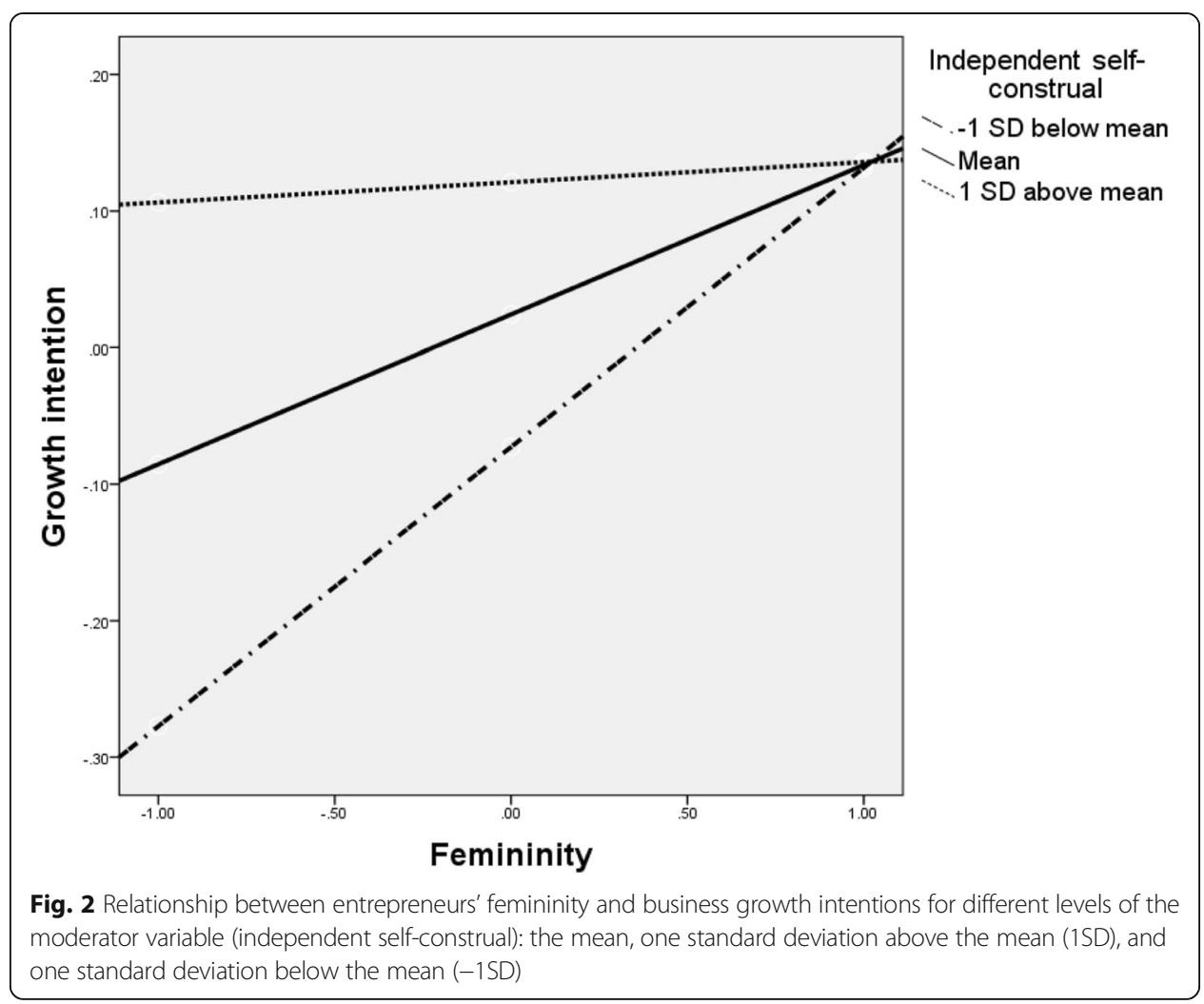

Broadly speaking, being a member of two traditionally unrelated groups (i.e., being a woman and an entrepreneur) is not an easy task for women. The image of the entrepreneur has traditionally been masculinized and rooted in masculine discourse (Ahl, 2006). According to Cross and Madson (1997), men endorse higher levels of independent self-construal than women. This suggests that cues or symbols in the entrepreneurial environment should make independent self-construal more accessible (Hong et al., 2000; Oyserman \& Sorensen, 2009). In our case, dual identifiers, such as female entrepreneurs, are required very often to adopt opposing sets of cultural proscriptions where the masculine is prioritized over the feminine (Bird \& Brush, 2002;

Table 3 Conditional indirect effect results of biological sex on business growth intentions at values of independent self-construal

\begin{tabular}{|c|c|c|c|c|}
\hline \multirow[b]{2}{*}{ Model } & \multirow[t]{2}{*}{ Mediator } & \multirow[t]{2}{*}{ Level of IND } & \multicolumn{2}{|c|}{ Business growth intention ${ }^{a}$} \\
\hline & & & Estimate & $95 \%$ Confidence interval \\
\hline \multirow{6}{*}{$\begin{array}{l}\text { Biological sex (via gender identity) on } \\
\text { business growth intent }\end{array}$} & \multirow[t]{3}{*}{ Femininity } & $-1 S D$ & 0.11 & 0.03 to 0.20 \\
\hline & & Mean & 0.03 & 0.01 to 0.07 \\
\hline & & $+1 S D$ & 0.00 & -0.02 to 0.03 \\
\hline & \multirow[t]{3}{*}{ Masculinity } & $-1 S D$ & -0.04 & -0.10 to -0.01 \\
\hline & & Mean & -0.03 & -0.08 to -0.008 \\
\hline & & $+1 S D$ & -0.025 & -0.08 to 0.008 \\
\hline
\end{tabular}

$N=572$

SE standard error, IND independent self-construal

${ }^{a}$ Control variables = firm age, number of employees, firm performance, entrepreneur's age, education, internal locus of control, and perceived behavioral control

${ }^{b}$ Bias corrected and accelerated confidence intervals are reported. Bootstrap sample size $=5000$ 
Coleman, 2016). Bjursell and Bäckvall (2011) provided empirical insights into how the mother role is taken for granted while the business role is approached as problematic in portrayals of women in family business. Our results provide evidence that under high levels of independent self-construal, female entrepreneurs are not willing to grow their ventures as women in lower levels of independent self-construal. Further research is needed to explore the reasons behind females' lower growth intention. Certainly, issues of individual motivation factors such as ego-depletion (Baumeister et al. 1998) could be explored. However, issues to do with the social context should also be explored. This research took place in country at southern Europe, where the general cultural mandate is towards interdependence. Self-construal orientations have shown to interact with nation-level cultural orientation to influence entrepreneurship intentions (Siu \& Lo, 2013), and further research should explore the contribution of those in women entrepreneurship.

The findings of the present study demonstrate that masculinity and femininity completely mediated the influence of sex on growth intentions, after controlling for the effects of perceived behavioral control and internal locus of control. The precise measure of femininity as well as masculinity allows us to look at how gender identity affects the sex and growth intentions relationships. In our study, femininity was measured by asking participants to rate themselves with words or phrases such as "warm, gentle, affectionate, sympathetic, sensitive to others' needs, and tender." Masculinity was measured by asking participants to rate themselves with words or phrases such as "leadership abilities, possessing strong personality, dominant, act like a leader, make decision easily, and defend own beliefs." Those traits are related to business growth, and our conceptual mediation model is supported by our data explaining in part how a biological construct like entrepreneurs' sex can relate to business growth, that is, our work documents that growth intentions reflect rational trade-offs among both financial and nonfinancial factors (Eddleston \& Powell, 2008; Jennings \& Brush, 2013).

In line with previous research (Eddleston \& Powell, 2008), we have found that women entrepreneurs reported more feminine than masculine traits and that men entrepreneurs endorsed more masculinity than femininity traits. However, cross-tabulation analysis results of entrepreneurs by sex and gender identity suggested that male entrepreneurs were almost equally split between a masculine identity (56.3\%) and a feminine identity (43.7\%) compared to the percentage of women entrepreneurs categorized as feminine (71\%). This finding suggests the existence of substantial heterogeneity in gender identity among male entrepreneurs whereas women entrepreneurs exhibited a rather stereotypical feminine orientation. An alternative explanation however may rest on the fact that Bem's Sex Role Inventory (1981) uses adjectives representing masculine and feminine gender identities that were selected 35 years ago and, therefore, do not accurately portray male and female entrepreneurs today.

Our study has some practical implications for business policy formulation and the teaching of entrepreneurship which form part of a strategy directed at increasing the growth of established firms. The findings suggest that the development of business growth intention is a complex phenomenon that may be influenced by gender identity. Entrepreneurial educators should craft strategies and learning environments that validate and stimulate womens' identity in a way that does not emulate the behavior of the idealized male entrepreneur. Moreover, educators should gain a better general understanding of how womens' entrepreneurial intentions are formed, as well as a specific 
understanding of how entrepreneur' gender identity and independent self-construal merge into the intent to growth a business.

Our study has also some implications for innovation policy. Contemporary research suggests that public resource distribution to innovation processes have to large extent directed to manufacturing industries and new technologies, both primarily employing men as employees and entrepreneurs and not to the service industries employing mostly women or both men and women to the same extent (Lindberg, 2012; Pettersson \& Lindberg, 2013). This suggests that innovation policies have primarily promoted innovation in a narrow spectrum of sectors and innovation types.

Although in the entrepreneurship the individual is visible, in the innovation policy, the individual is made invisible, yet research suggests that we can still see a clear construction of masculinity in how and where innovation is expected to come about. Moreover, men are ascribed a normative role in innovation policies and innovation networks (Lindberg, 2012). Taking into account that entrepreneurship which is based on knowledge will be the primary driver of innovation in the twenty-first century (see Carayannis et al. 2015), then researchers and policy makers should also examine whether rules, norms, and general practices in the innovation process are dominated by masculine values and the innovation policy discourses are constructed against a background of combined masculinities.

This research has some limitations. Firstly, the primary study variables were measured with the use of a single survey, and as such, common method variance could be a problem. However, it should be noted that findings from our confirmatory factor analyses indicated that common method variance is unlikely to influence the results. Second, our research was limited to a sample of entrepreneurs from Greece. To guarantee the generalizability of our results, we encourage scholars in this area to examine our proposed model with entrepreneurs across different countries. Third, it is plausible that male and female entrepreneurs may have been motivated by societal expectations to see themselves as differing in ways consistent with generally accepted gender stereotypes even if they did not actually differ in these ways. Fourth, as previously stated, we acknowledge that gender schemas have been through a significant shift since BSRI was put into use in the 1970s which presents challenges with respect to measuring gender identity in a valid way. However, recent studies provide evidence that the BSRI has been proven to be valid instrument (Carver et al., 2013; Vafaei et al., 2014). These limitations represent, in any case, opportunities to advance in our efforts to better understand business growth.

\section{Conclusions}

The findings of the present study make it clear that business growth intention is a complex phenomenon that may be influenced by gender. Our results indicate that gender identity mediates the influence of sex on business growth intentions and the mediation effects are contingent on entrepreneurs' independent self-construal. Thus, women make decisions related to the growth of their businesses using a different process than men do. Our results reinforce the claims that it is valuable to incorporate a feminine perspective when studying the factors influencing entrepreneurs' growth intentions in established business. 


\section{Acknowledgements}

Research reported herein was fully supported via a Grant financed by the European Economic Area (EEA) Financial Mechanism and the Greek Secretariat for Research and Technology (GSRT) ("FOREMOST" project: 3864). Views, opinions, and results reported herein are the sole responsibility of the authors and do not correspond to official EEA or GSRT position.

\section{Authors' contributions}

Authors contributed equally to this manuscript. All authors read and approved the final manuscript.

\section{Competing interests}

The authors declare that they have no competing interests.

\section{Author details}

${ }^{1}$ Technical University of Crete, School of Production Engineering and Management, University Campus, Chania, Crete 73100, Greece. ${ }^{2}$ Department of Psychology, University of Crete, Gallos Campus, Rethymnon, Crete 74100, Greece.

Received: 20 June 2016 Accepted: 7 October 2016

Published online: 18 October 2016

\section{References}

Ahl, H. (2006). Why research on women entrepreneurs needs new directions. Entrepreneurship Theory \& Practice, 30(5), 595-621.

Ahl, H., \& Marlow, S. (2012). Exploring the dynamics of gender, feminism and entrepreneurship: advancing debate to escape a dead end? Organization Science, 19(5), 543-562.

Ajzen, I. (1991). The theory of planned behavior. Organizational Behavior and Human Decision Processes, 50, 179-211.

Arbuckle, J. L. (2006). AMOS 7.0. user guide. Chicago: SmallWaters Corporation.

Baumeister, R. F., Bratslavsky, E., Muraven, M., \& Tice, D. M. (1998). Ego depletion: is the active self a limited resource? Journal of Personality and Social Psychology, 74(5), 1252-1265.

Bem's Sex Role Inventory. (1981). Gender schema theory: a cognitive account of sex typing. Psychological Review, 88(4), 354-364. doi:10.1037/0033-295x.88.4.354.

Bird, B., \& Brush, C. (2002). A gendered perspective on organizational creation. Entrepreneurship Theory and Practice, 26(3), 41-66.

Bjursell, C., \& Bäckvall, L. (2011). Family business women in media discourse: the business role and the mother role Journal of Family Business Management, 1, 154-173.

Bulanova, O., Isaksen, E. J., \& Kolvereid, L. (2016). Growth aspirations among women entrepreneurs in high growth firms. Baltic Journal of Management, 11(2), 187-206.

Carayannis, E. G., Samara, E. T., \& Bakouros, Y. L. (2015). Innovation and entrepreneurship: theory, policy and practice. Heidelberg: Springer.

Carver, L. F., Vafaei, A., Guerra, R., Freire, A., \& Phillips, S. P. (2013). Gender differences: examination of the 12-item Bem Sex Role Inventory (BSRI-12) in an older Brazilian population. PLOS ONE, 8(10), e76356. doi:10.1371/journal.pone.0076356.

Cassar, G. (2006). Entrepreneur opportunity costs and intended venture growth. Journal of Business Venturing, 21(5), 610-632.

Chen, C. C., Greene, P. G., \& Crick, A. (1998). Does entrepreneurial self-efficacy distinguish entrepreneurs from managers? Journal of Business Venturing, 13(4), 295-316.

Cliff, J. E. (1998). Does one size fit all? Exploring the relationship between attitudes towards growth, gender, and business size. Journal of Business Venturing, 13(6), 523-542.

Cohen, J., Cohen, P., West, S. G., \& Aiken, L. S. (2003). Applied multiple regression/correlation analysis for the behavior sciences. Mahwah: Lawrence Erlbaum Associates.

Coleman, S. (2016). Gender, entrepreneurship, and firm performance: recent research and considerations of context. In M. L. Connerley \& J. Wu (Eds.), Handbook on well-being of working women (pp. 375-391). Dordrecht: Springer Science.

Cross, S. E., \& Madson, L. (1997). Models of the self: self-construals and gender. Psychological Bulletin, 122(1), 5-37.

Davis, A. E., \& Shaver, K. G. (2012). Understanding gendered variations in business growth intentions across the life course. Entrepreneurship Theory and Practice, 36(3), 495-515. doi:10.1111/j.1540-6520.2012.00508.x.

Delmar, F., \& Wiklund, J. (2008). The effect of small business managers' growth motivation on firm growth: a longitudinal study. Entrepreneurship Theory and Practice, 32(3), 437-457.

Dutta, D. K., \& Thornhill, S. I. (2008). The evolution of growth intentions: toward a cognition-based mode. Journal of Business Venturing, 23(3), 307-332.

Eddleston, K. A., \& Powell, G. N. (2008). The role of gender identity in explaining sex differences in business owners' career satisfier preferences. Journal of Business Venturing, 23(2), 244-256.

Edelman, L. F., Brush, C. G., Manolova, T. S., \& Greene, P. G. (2010). Start-up motivations and growth intentions of minority nascent entrepreneurs. Journal of Small Business Management, 48(2), 174-196.

Farmer, S. M., Yao, X., \& Kung-Mcintyre, K. (2011). The behavioral impact of entrepreneur identity aspiration and prior entrepreneurial experience. Entrepreneurship Theory and Practice, 35(2), 245-273.

Fauchart, E., \& Gruber, M. (2011). Darwinians, communitarians, and missionaries: the role of founder identity in entrepreneurship. Academy of Management Journal, 54(5), 935-957.

Fernández, l., Paez, D., \& González, J. L. (2005). Independent and interdependent self-construals and socio-cultural factors in 29 nations. Revue Internationale de Psychologie Sociale, 18(1), 35-63.

Gupta, V. K., Turban, D. B., Wasti, S. A., \& Sikdar, A. (2009). The role of gender stereotypes in perceptions of entrepreneurs and intentions to become an entrepreneur. Entrepreneurship Theory and Practice, 33(2), 397-417.

Haltiwanger, J. C., Lane, J. I., \& Spletzer, J. R. (1999). Productivity differences across employers: the roles of employer size, age, and human capital. The American Economic Review, 89(2), 94-98.

Hayes, A. F. (2013). Introduction to mediation, moderation, and conditional process analysis: a regression-based approach. New York: The Guilford Press. 
Henry, C., Foss, L., \& Ahl, H. (2016). Gender and entrepreneurship research: a review of methodological approaches. International Small Business Journal, 34(3), 217-341.

Hoang, H., \& Gimeno, J. (2010). Becoming a founder: how founder role identity affects entrepreneurial transitions and persistence in founding. Journal of Business Venturing, 25(1), 41-53.

Hong, Y. Y., Morris, M. W., Chiu, C. Y., \& Benet-Martinez, V. (2000). Multicultural minds: a dynamic constructivist approach to culture and cognition. American Psychologist, 55(7), 709-720.

Ireland, R. D., \& Webb, J. W. (2007). A cross-disciplinary exploration of entrepreneurship research. Journal of Management, 33(6), 891-927.

Jennings, J. E., \& Brush, C. G. (2013). Research on women entrepreneurs: challenges to (and from) the broader entrepreneurship literature? Academy of Management Annals, 7(1), 661-713.

Kerfoot, D., \& Miller, C. (2010). Organizing entrepreneurship? Women's invisibility in self-employment. In P. Lewis \& S. Ruth (Eds.), Revealing and concealing gender (pp. 100-123). UK: Palgrave Macmillan.

Krueger, N. F., Reilly, M. D., \& Carsrud, A. L. (2000). Competing models of entrepreneurial intentions. Journal of Business Venturing, 15(5), 411-432.

Lewis, P. (2006). The quest for invisibility: female entrepreneurs and the masculine norm of entrepreneurship. Gender, Work \& Organization, 13(5), 453-469.

Linan, F., \& Chen, Y. W. (2009). Development and cross-cultural application of a specific instrument to measure entrepreneurial intentions. Entrepreneurship Theory and Practice, 33(3), 593-617.

Lindberg, M. (2012). A striking pattern co-construction of innovation, men and masculinity in Sweden's innovation policy. In S. Andersson, K. Berglund, E. Gunnarsson, \& E. Sundin (Eds.), Promoting innovation: policies, practices and procedures. Stockholm: VINNOVA/Swedish Governmental Agency for Innovation System.

Markus, H. R., \& Kitayama, S. (1991). Culture and the self: implications for cognition, emotion, and motivation. Psychological Review, 98(2), 224-253.

Menzies, T. V., Diochon, M., \& Gasse, Y. (2004). Examining venture-related myths concerning women entrepreneurs. Journal of Developmental Entrepreneurship, 9, 89-107.

Miller, C. C., Washburn, N. T., \& Glick, W. H. (2013). Perspective-the myth of firm performance. Organization Science, 24(3), 948-964.

Mueller, S. L. (2004). Gender gaps in potential for entrepreneurship across countries and cultures. Journal of Developmental Entrepreneurship, 9(3), 199-220.

Oppenheimer, D. M., Meyvis, T., \& Davidenko, N. (2009). Instructional manipulation checks: detecting satisficing to increase statistical power. Journal of Experimental Social Psychology, 45(4), 867-872.

Oyserman, D., \& Sorensen, N. (2009). Understanding cultural syndrome effects on what and how we think: a situated cognition model. In R. S. Wyer, C. Chi-yue, \& Y. Y. Hong (Eds.), Understanding culture: theory, research and application (pp. 25-52). New York: Taylor \& Francis Group.

Oyserman, D., Coon, H. M., \& Kemmelmeier, M. (2002). Rethinking individualism and collectivism: evaluation of theoretical assumptions and meta-analyses. Psychological Bulletin, 128, 3-72.

Pettersson, K., \& Lindberg, M. (2013). Paradoxical spaces of feminist resistance: mapping the margin to the masculinist innovation discourse. International Journal of Gender and Entrepreneurship, 5(3), 323-341.

Podsakoff, P. M., MacKenzie, S. B., Lee, J. Y., \& Podsakoff, N. P. (2003). Common method biases in behavioral research: a critical review of the literature and recommended remedies. Journal of Applied Psychology, 85(5), 879-903.

Preacher, K. J., \& Kelley, K. (2011). Effect size measures for mediation models: quantitative strategies for communicating indirect effects. Psychological Methods, 16(2), 93-115.

Rauch, A., \& Frese, M. (2000). Psychological approaches to entrepreneurial success. A general model and an overview of findings. In c. L. Cooper, \& I. T. Robertson (Eds.), International Review of Industrial and Organizational Psychology (pp. 101-142). Chichester: Wiley.

Sadler-Smith, E., Hampson, Y., Chaston, I., \& Badger, B. (2003). Managerial behavior, entrepreneurial style, and small firm performance. Journal of Small Business Management, 41(1), 47-67.

Shane, S. (2009). Why encouraging more people to become entrepreneurs is bad public policy. Small Business Economics, 33(2), 141-149.

Shepherd, D., \& Haynie, J. M. (2009). Family business, identity conflict, and an expedited entrepreneurial process: a process of resolving identity conflict. Entrepreneurship Theory and Practice, 33(6), 1245-1264.

Shook, C. L., Ketchen, D. J. J., Hult, G. T. M., \& Kacmar, K. M. (2004). An assessment of the use of structural equation models in strategic management research. Strategic Management Journal, 25, 397-404.

Shrout, P. E., \& Bolger, N. (2002). Mediation in experimental and non-experimental studies: new procedures and recommendations. Psychological Methods, 4, 422-445.

Singelis, T. M. (1994). The measurement of independent and interdependent self-construals. Personality and Social Psychology Bulletin, 20, 580-591.

Siu, W. S., \& Lo, E. S. C. (2013). Cultural contingency in the cognitive model of entrepreneurial intention. Entrepreneurship Theory and Practice, 37, 147-173.

Stam, E., Suddle, K., Hessels, J., \& van Stel, A. (2009). High-growth entrepreneurs, public policies and economic growth. In J. Leitao \& R. Baptista (Eds.), Public policies for fostering entrepreneurship: a European perspective (pp. 91-110). New York: Springer.

Tang, L., \& Koveos, P. E. (2004). Venture entrepreneurship, innovation entrepreneurship and economic growth. Journal of Developmental Entrepreneurship, 3, 161-171.

Vafaei, A., Alvarado, B., Tomás, C., Muro, C., Martinez, B., \& Zunzunegui, M. V. (2014). The validity of the 12-item Bem Sex Role Inventory in older Spanish population: an examination of the androgyny model. Archives of Gerontology and Geriatrics, 59(2), 257-263.

Van Praag, C. M., \& Versloot, P. (2007). What is the value of entrepreneurship? A review of recent research. Small Business Economics, 29(4), 351-382.

Venugopal, V. (2016). Investigating women's intentions for entrepreneurial growth. International Journal of Gender and Entrepreneurship, 8(1), 2-27. 
Wiklund, J., \& Shepherd, D. (2003). Aspiring for, and achieving growth: the moderating role of resources and opportunities. Journal of Management Studies, 40(8), 1919-1941.

Wiklund, J., Davidsson, P., \& Delmar, F. (2003). What do they think and feel about growth? An expectancy-value approach to small business managers' attitudes toward growth. Entrepreneurship Theory and Practice, 27(3), 247-270.

Wood, W., \& Eagly, A. H. (2010). Gender. In S. T. Fiske, D. T. Gilbert, \& G. Lindzey (Eds.), Handbook of social psychology (5th ed., Vol. 1, pp. 629-667). Hoboken: Wiley.

Zampetakis, L. A., Lerakis, M., Kafetsios, K., Moustakis, V. (2015). Investigating the role of self-construal in the formation of entrepreneurial intentions. Frontiers in Psychology - Organizational Psychology, 6(1085), doi:10.3389/fpsyg.2015.01085

Zhao, X., Lynch, J. G., \& Chen, Q. (2010). Reconsidering Baron and Kenny: myths and truths about mediation analysis. Journal of Consumer Research, 37(2), 197-206.

\section{Submit your manuscript to a SpringerOpen ${ }^{\circ}$ journal and benefit from:}

- Convenient online submission

- Rigorous peer review

- Immediate publication on acceptance

- Open access: articles freely available online

- High visibility within the field

- Retaining the copyright to your article

Submit your next manuscript at $>$ springeropen.com 